\title{
KOMUNIKASI TUAN GURU SEBAGAI MOTIVATOR DI PESANTREN
}

\author{
Firdaus Yuni Dharta ${ }^{1}$ dan Engkus Kuswarno ${ }^{2}$ \\ ${ }^{1}$ Staf Dit PSMP Kementrian Pendidikan dan Kebudayaan Jakarta \\ ${ }^{2}$ Guru Besar Fakultas IImu Komunikasi Universitas Padjadjaran \\ Email : fiyudha2004@yahoo.com
}

\begin{abstract}
ABSTRAK. Penelitian tentang Komunikasi Tuan Guru sebagai motivator di Pesantren dilakukan di beberapa pondok pesantren di Pulau Lombok, Provinsi Nusa Tenggara Barat. Penelitian ini berdasarkan pada fenomena rendahnya motivasi masyarakat untuk mengikuti pendidikan, ketidakberdayaan masyarakat serta rendahnya tingkat partisipasi masyarakat. Dengan menggunakan pendekatan interaksi simbolis, penelitian ini dimaksudkan untuk menjawab pertanyaan penelitian yaitu bagaimanakah Komunikasi Tuan Guru untuk memotivasi masyarakat, memberdayakan masyarakat, dan meningkatkan partisipasi masyarakat. Metode pengumpulan data dilakukan melalui pengamatan partisipatif dan wawancara mendalam dengan sejumlah informan kunci yang berasal dari beberapa pondok pesantren yang terdapat di Pulau Lombok, Provinsi Nusa Tenggara Barat. Hasil penelitian menunjukkan bahwa Tuan Guru berinteraksi dengan masyarakat, siswa dan santri dengan menggunakan dua bentuk komunikasi yaitu komunikasi lisan (verbal), komunikasi bilhal, dan integrasi antara komunikasi lisan dan bilhal. Integrasi antara komunikasi lisan (verbal) dan komunikasi bilhal mengubah pandangan tentang Tuan Guru dari Tuan Guru sebagai agamawan tradisional kepada Tuan Guru sebagai agawaman organisasi yang tidak mahir atau berpengetahuan tentang Kitab Kuning tetapi juga membumikan pengetahuan Kitab Kuning dalam perbuatan praksis (Kitab Hijau) yang bermanfaat bagi kehidupan masyarakat melalui kegiatan pendidikan, penghijauan, perekonomian dan pemberdayaan masyarakat. Dalam berinteraksi dengan masyarakat, siswa dan santri, Tuan Guru tidak hanya menggunakan simbol-simbol verbal berupa kata-kata, ucapan, isyarat, kinestik; tetapi juga menggunakan simbol perbuatan nyata dalam kehidupan praksis masyarakat. Integrasi antara Kitab Kuning dan Kitab Hijau pada akhirnya tersebut menjadi basis kepercayaan masyarakat kepada Tuan Guru yang memotivasi masyarakat, meningkatkan partisipasi masyarakat, dan memberdayakan masyarakat.
\end{abstract}

Kata Kunci: Komunikasi Tuan Guru, Komunuikasi bil-hal, Komunikasi bil-lisan, Intektual Tradisional

\section{COMMUNICATION OF TUAN GURU AS A MOTIVATOR IN ISLAMIC BOARDING SCHOOL}

ABSTRACT. The study on Tuan Guru's communication as a motivator was conducted in several Islamic Boarding Schools in Lombok Island, Province of West 
Nusa Tenggara. The study was based on the phenomena of community's low motivation, low participation, and powerlessness in education. Through the symbolic interaction approach, this study was aimed at three research questions; i.e., how Tuan Gurus interacted with their communities to motivate citizens, empower communities and enhance citizen participation in education. Data were collected through participatory observation and in-depth interview with rich case informants (Tuan Gurus) from several Islamic Boarding Schools in Lombok, Province of NTB. The findings of this study were that Tuan Gurus interacted with their communities through oral communication, bilhal communication and integrated oral and bilhal communication. The integration of oral and bilhal communication changed the viewpoint of Tuan Gurus from those as traditional intellectuals to those as organic intellectuals, who were not only capable of Kitab Kuning, but also earthed the knowledge of Kitab Kuning into real programs or activities for the community (Kitab Hijau) through educational, environmental, economic and community empowerment programs. In interacting with their communities, students, and santries, The integration between Kitab Kuning and Kitab Hijau became the basis of trust-based relationship between communities and Tuan Gurus which in turn made Sasak's communities motivated to care about education, empowered communities and enhance communities participation in education

Keywords : bil-lisan communication, bil-hal communication, tuan guru communication, traditional intellectuals

\section{PENDAHULUAN}

Perkembangan agama Islam di Lombok seiring dengan bermunculmya para penyebar Islam (juru dakwah) seperti yang telah diajarkan oleh Sunan Giri untuk membebaskan masyarakat dari paham animisme menjadi masyarakat agamis yaitu islami. Setelah itu lahirlah sosok-sosok ulama lombok yang dimulai pada awal abad ke-20 yang disebut sebagai Tuan Guru. Tuan Guru adalah sebutan atau panggilan kepada seseorang yang alim yang memiliki pengetahuan agama yang luas dan mendalam untuk meneruskan dakwah dari para pendahulunya yang telah meninggalkan warisan intelektual sangat berharga serta membebaskan mayarakat dari kebodohan dan keterbelakangan akibat kolonialisme Belanda.

Tuan Guru di Lombok sekarang sudah merupakan bagian dari stakeholders (pemangku kepentingan) mempunyai tanggung jawab yang sama juga dengan pemangku kepentingan daerah. Tuan Guru baik Sebagai pengasuh pondok, tokoh masyarakat, pengasuh madrasah, pengurus/anggota partai politik, dan kepala rumah tangga mempunyai posisi strategis untuk memotivasi, meningkatan partisipasi dan memberdayakan masyarakat Pulau Lombok untuk mengikuti dan melanjutkan pendidikan. Untuk mencapai tujuan ini, tuan guru dengan ketokohannya di bidang asketis, pendidikan dan politik dituntut untuk berkomunikasi dengan masyarakat, orang tua peserta didik, pemda dan tokoh 
masyarakat sehingga semakin banyak masyarakat (peserta didik) tergerak untuk mengikuti pendidikan di Pulau Lombok .

Keberhasilan tersebut sangat ditentukan oleh sarana, tujuan, dan aksi komunikasi yang dibangun Tuan Guru dalam kaintannya dengan masyarakat, orang tua, calon peserta didik. Tuan Guru memiliki pola komunikasi yang berbeda karena di samping sebagai tokoh agama, mereka juga berperan sebagai tokoh masyarakat, tokoh pendidikan, tokoh politik, dan sekaligus kepala keluarga. Mereka juga membangun komunikasi secara langsung dengan para peserta didik yang kehidupan setiap harinya dihabiskan di lingkungan di mana mereka tinggal. Proses, gaya dan pola komunikasi yang digunakan oleh Tuan Guru akan tampak ketika mereka berkomunikasi dengan masyarakat, orang tua, calon peserta didik, sekolah dan para guru.

Komunikasi Tuan Guru dianggap penting karena mereka membantu memotivasi masyarakat, meningkatkan partisipasi masyarakat dan memberdayakan masyarakat terutama dalam hal pendidikan. Kepedulian masyarakat terhadap pendidikan mendorong masyarakat untuk menyekolahkan anak-anak mereka di madrasah atau pesantren. Ketokohan tuan guru tersebut membantu mendorong agar semakin banyak masyarakat mengikuti pendidikan terutama untuk (a) menangani masyarakat yang selama ini terkecualikan atau terabaikan, misalnya masyarakat miskin; (b) memberdayakan kaum perempuan yang hampir selalu kurang diuntungkan dalam proses pembangunan masyarakat termasuk dalam pendidikan.

Kedudukan tuan guru dalam memotivasi masyarakat agar peduli terhadap pendidikan mengharuskan para tuan guru trampil berkomunikasi sabagai sarana pembangunan pendidikan. Tiap tuan guru seyogianya mengkomunikasi pesanpesan pendidikan/pengajaran secara bijak, santun dan arif. Untuk meningkatkan kemampuan komunikasi mereka, tuan guru harus menyadari bahwa komunikasi antara tuan guru dan masyarakat dan calon peserta didik memiliki arti yang sangat luas, termasuk gerak-gerik isyarat, pakaian, maupun dalam bentuk perlambangan lainnya yang berlaku di lembaga pendidikan.

Dengan demikian maka akan timbul pertanyaan Bagaimanakah komunikasi yang dilakukan oleh Tuan Guru dalam memotivasi masyarakat, meningkatkan partisipasi masyarakat dan memberdayakan masyarakat?

\section{METODE}

Informan dalam penelitian ini adalah para Tuan guru yang ada di Pondok Pesantren di Pulau Lombok. Sedangkan penentuan dan pemilihan informan kunci yaitu para tuan guru yang memenuhi syarat rich case and good informants yakni menyampaikan data apa adanya secara terbuka, jujur, enak bicara dan dapat berkomunikasi dengan baik yang dilakukan secara snowball. Wawancara mendalam dilakukan untuk mendapatkan data yang akurat dan terbaru. 


\section{HASIL DAN PEMBAHASAN}

Komunikasi dalam Pemberdayaan Masyarakat

Hasil penelitian menunjukkan bahwa ada beberapa alasan mendasar mengapa Tuan Guru melakukan tindakan komunikasi untuk memberdayakan masyarakat.

Pertama, Tuan Guru melakukan tindakan komunikasi untuk memberdayaakan masyarakat disebabkan oleh adanya dorongan illahi dari Allah untuk turun tangan untuk memberdayakan masyarakat. Dorongan illahi dari Allah tersebut diwujudkan melalui kegiatan dakwah. Kegiatan dakwah menjadi kavling atau bagian Tuan Guru tradisional. Hal ini dilakukan sebagai bentuk penghayatan imannya kepada Allah. Seluruh perkataan, sikap dan perbuatan Tuan merupakan bentuk dakwah.

Kesatuan antara perkataan dan perbuatan menjadi karakterisitik utama dari tuan guru tradisional yang menekankan dakwah lisan dan dakwah bilhal dalam memberdayakan masyarakat. Dakwah lisan dimaksudkan untuk memberikan pemahaman kepada masyarakat tentang realitas kehidupan mereka, melatih dan membina masyarakat sehingga mereka mempunyai kemampuan tertentu yang dapat menunjang kehidupan mereka sendiri. Dakwah bilhal diperlihatkan oleh Tuan Guru melalui contoh praktis seperti memberikan pelatihan anyaman dan menanam tanaman produktif yang bisa membantu masyarakat meningkatkan ekonomi mereka.

Kedua, Tuan Guru melakukan tindakan komunikasi untuk memberdayakan masyarakat terdorong oleh keprihatinan pribadi atas kondisi masyarakat yang miskin dan yang rendah pendidikan mereka. Keprihatinan atau kegelisahan Tuan Guru atas kondisi kehidupan masyarakat diungkapkan oleh Tuan Guru Haji Hasanain dan Tuan Guru Haji Ayudin, Lc.

Sebagai wujud dari kegelisahannya atas ketidakberdayaan kaum Tuan Guru, Tuan Guru Haji Hasanain Juaini mendirikan pondok pesantren yang khusus menampung santri perempuan. Di pondok pesantren, Tuan Guru tidak hanya mengajarkan tentang keagamaan tetapi mengajarkan aplikasi pengetahuan tentang al-Qur'an, al-Hadiths, dan Kitab Kuning dalam kehidupan praktis melalui kegiatan penghijauan lingkungan. Hal ini lebih dikenal dengan istilah 'kitab hijau' karena kiprahnya dan kepedulian Tuan Guru terhadap lingkungan dan kehidupan berdemokrasi.

Hal yang sama juga dilakukan oleh Tuan Guru Haji Ayudin, Lc, yang memadukan komunikasi lisan dan komunikasi bilhal untuk memberdayakan masyarakat. Tuan Guru, setelah menamatkan pendidikan di Cairo, tergerak hatinya untuk memperbaiki kondisi masyarakat di tempat asalnya. Hal ini dilakukan karena Tuan Guru beranggapan bahwa 'hanya orang sendiri yang mau berbuat sesuatu bagi daerahnya'. Dengan kata lain, Tuan Guru tidak dapat berbuat sesuatu bagi daerahnya kalau Tuan Guru berada di tempat lain. Artinya, kalau bukan orang lain, siapa lagi; kalau bukan sekarang, kapan lagi; dan kalau tidak di sini, di mana lagi.

Kesadaran diri atau motif individual tersebutlah yang mendorong Tuan Guru formal seperti TGH Hasanain Juaini dan TGH Ayudin, LC untuk memberdayakan masyarakat. Model pemberdayaan yang dilakukan oleh kedua Tuan Guru ini lebih 
menekankan aspek bilhal. Hal ini disebabkan karena masyarakat lebih cepat memahami oleh karena mereka melihat langsung apa yang dikerjakan oleh Tuan Guru untuk memberdayakan masyarakat.

Hal yang berbeda dilakukan oleh Tuan Guru yang juga berprofesi sebagai seorang politikus. Sosok Tuan Guru memiliki peran sentral dalam masyarakat. Tuan Guru dalam dijadikan sebagai referensi atau rujukan dalam berbagai bidang kehidupan, tidak saja persoalan agama, tetapi juga persoalan sosial, politik, ekonomi hingga budaya. Hasil penelitian menunjukkan bahwa paling tidak ada tiga alasan mendasar yang melatarbelakangi kecenderungan Tuan Guru untuk memberdayakan masyarakat melalui ranah politik praktis. Pertama, alasan teologis. Mayoritas ulama Sunni mengemukakan bahwa dalam Islam tidak ada pemisahan antara agama (din) dengan politik (siyasah), karena itu politik dipandang sebagian integral dari agama. Kedua, alasan moralitas, artinya ada citra yang dibangun oleh masyarakat (termasuk Tuan Guru) bahwa sangat sulit mencari manusia yang independen yang bisa menjembatani kepentingan rakyat dengan pemerintah dan masih sulitnya menegakan moralitas pada domain politik. Ketiga,lebih disebabkan alasan ekonomi atau kekuasaan semata, artinya profesi politisi lebih menjanjikan dibandingkan dengan profesi lainnya.

Tindakan Tuan Guru untuk memberdayakan masyarakat didasarkan pada kondisi riil masyarakat berupa (a) lemahnya askes masyarakat untuk menyampaikan aspirasi, dukungan dan tuntutannya kepada pemerintah; (b) lemahnya masyarakat untuk mempengaruhi proses pemenuhan tuntutan tersebut; dan (c) rendahnya kemampuan masyarakat dalam menggunakan produk pemerintahan; dan (d) masyarakat tidak mampu berfungsi, berintegrasi dan bersinergi di dalam sistem bangsa (Ndraha, 1997:62).

Hasil penelitian juga memperlihatkan adanya Tuan Guru yang berprofesi sebagai pegawai negeri sipil. Hal inilah yang dilakukan oleh Tuan Guru Haji MS Udin, MA. Keterlibatan Tuan Guru secara struktural sebagai Asisten I dilatarbelakangi oleh sikap bahwa tidak perlu ada yang dipersoalkan dan tidak ada yang salah dari sikap yang diambil Tuan Guru, karena itu adalah hak demokrasinya selaku warga negara. Selain itu, Tuan Guru sebaiknya selalu berada pada posisi netral, menjaga suara moral kenabian dan tidak berpihak kepada suatu kekuatan politik manapun agar masyarakat tidak terpragmentasi dan terkotak-kotak.

Kehadiran tuan guru di pulau seribu masjid memberikan nuansa berbeda. Bahkan menjadi ciri khas tersendiri buat masyarakatnya. Pengaruhnya dapat terasa diberbagai bidang, tidak hanya di bidang pendidikan, di bidang politik, tetapi juga di bidang eksekutif. Salah satu alasan yang dikemukakan oleh Tuan Guru adalah menjalankan peran sosialnya sebagai penghubungan antara umat dan pemerintah. Peran ini pada dasarnya bukan peran sosial yang seharusnya diperankan oleh Tuan Guru, akan tetapi peran yang dikondisikan oleh pemerintah. Peran sebagai mediator ini kadang-kadang membuat Tuan Guru berada dalam posisi dilematis di mana Tuan Guru di satu sisi adalah tokoh masyarakat yang harus membela kepentingan masyarakat dan lembaga keagamaan, akan tetapi di 
sisi lain kadang-kadang harus membantu pemerintah dalam rangka melaksanakan program mereka yang kadang kala sangat sensitif dan bila tidak berhati-hati hal tersebut justru bisa merusak kewibawaan Tuan Guru di tengah masyarakat.

Selain because motive, tindakan komunikasi Tuan Guru untuk memberdayakan masyarakat juga ditentukan oleh in-order-to motive. Sebagaimana dijelaskan oleh Schultz (1967:132), in-order-to motive mengacu pada masa depan dan identik dengan objek atau maksud perwujudan dari tindakan yang adalah alat: itulah sebuah 'terminus ad quem'. Dengan demikian, tindakan komunikasi Tuan Guru untuk memberdayakan masyarakat tidak ditentukan oleh pengalaman masa silam Tuan Guru, tetapi ditentukan oleh maksud atau tujuan untuk memberdayakan masyarakat. Visi dan misi Tuan Guru tersebut adalah pendorong yang paling banyak berperan dalam memberdayakan masyarakat.

Sebagai seorang Tuan Guru tradisional, Tuan Guru berinteraksi untuk memberdayakan masyarakat dengan tujuan untuk melakukan perubahan sosial di masyarakat akar rumput Dalam kehidupan suatu masyarakat, peran seorang pemimpin sangat penting. Sebagai seorang tokoh masyarakat, kehadiran Tuan Guru secara umum dalam suatu masyarakat, mengemban tugas dan tanggung jawab yang besarjuga.

Sosok Tuan Guru menjadi begitu penting bahkan sangat dibutuhkan dalam kelangsungan kehidupan suatu masyarakat. Sedikitnya ada empat alasan tentang urgensi Tuan Guru tradisional yaitu : (1) karena banyaknya kelompok atau masyarakat yang membutuhkan figur pemimpin, (2) dalam beberapa situasi seorang pemimpin perlu tampil mewakili kelompok, (3) sebagai tempat pengambilalihan resiko bila terjadi masalah terhadap kelompoknya, (4) sebagai tempat untuk meletakkan kekuasaan. Berdasarkan hal tersebut adalah suatu keharusan untuk menentukan seorang Tuan Guru dalam suatu masyarakat, bangsa atau Negara.

Sebagai Tuan Guru formal, Tuan Guru berkomunikasi atau berinteraksi dengan masyarakat untuk (a) mengembangkan kemampuan masyarakat; (b) mengubah perilaku masyarakat; dan (3) mengorganisir diri masyarakat. Kemampuan masyarakat yang dapat dikembangkan tentunya banyak sekali seperti kemampuan untuk berusaha, kemampuan untuk mencari informasi, kemampuan untuk mengelola kegiatan, kemampuan dalam pertanian sesuai dengan kebutuhan atau permasalahan yang dihadapi oleh masyarakat. Perilaku masyarakat yang perlu diubah tentunya perilaku yang merugikan masyarakat atau yang menghambat peningkatan kesejahteraan masyarakat. Pengorganisasian masyarakat dapat dijelaskan sebagai suatu upaya masyarakat untuk saling mengatur dalam mengelola kegiatan atau program yang mereka kembangkan. Disini masyarakat dapat membentuk panitia kerja, melakukan pembagian tugas, saling mengawasi, merencanakan kegiatan, dan lain-lain. Lembaga-lembaga adat yang sudah ada sebaiknya perlu dilibatkan karena lembaga inilah yang sudah mapan, tinggal meningkatkan kemampuannya saja. 
Sebagai seorang Tuan Guru yang politikus, orientasi Tuan Guru terjun ke ranah politik diletakan pada kerangka "amar ma'ruf nahi munkar" dalam artian mengawasi dan mengevaluasi. Pada tatanan ini, amar ma'ruf nahi munkar yang ingin diperankan para Tuan Guru pada domain politik, sepintas kelihatannya memiliki peran signifikan karena fakta tatanan sosial politik Indonesia banyak yang tidak sejalan dengan moralitas kenabian atau ajaran agama. Berbagai bentuk kebobrokan yang terjadi, mulai dari tindakan a-susila yang dilakukan oleh oknum tertentu, KKN dan perilaku para pemimpin serta pemegang otoritas kekuasaan yang tidak berdasarkan kepada landasan moralitas kenabian dan nilai-nilai agama. Perilaku yang dipertontonkan pemegang kekuasaan terkesan semaunya, mumpung punya kuasa, bahkan yang paling parah tanpa memperdulikan terhadap kepentingan dan kesejahteraan rakyat.

\section{Komunikasi dalam meningkatkan Partisipasi Masyarakat}

Fenomena rendahnya partisipasi masyarakat dalam program dan kegiatan pondok pesantren dapat dilihat sebagai seuatu fenomena umum yang terjadi di Pulau Lombok. Hal ini dapat dicermati dari sudut keterlibatan masyarakat dalam program-program pondok pesantren. Berdasarkan Laporan dari Dinas Pendidikan Lombok Barat, Kabupaten Lombok mempunyai tingkat partisipasi pendidikan yang terendah di antara 9 kabupaten/kota yang ada di Provinsi Nusa Tenggara Barat.

Hasil penelitian menemukan bahwa Tuan Guru merupakan aktor utama yang berperan mengkomunikasikan program pendidikan dasar kepada masyarakat di Pulau Lombok. Selain itu, Tuan Guru merupakan salah satu unsur tokoh masyarakat yang paling sering ditemui oleh masyarakat atau yang memiliki kontak hampir setiap hari. Frekuensi komunikasi antara komunikator (Tuan Guru) dan komunikan (masyarakat Lombok Barat) menentukan penilaian masyarakat tentang efektivitas prgoram-program pondok pesantren. Persepsi masyarakat penerima program pendidikan (komunikan) dan adanya nilai tambah (value-added) dari program program yang ditawarkan oleh pondok pesantren berakibat pada meningkatnya tingkat partisipasi masyarakat dalam program atau kegiatan pondok pesantren. Tingkat partisipasi pendidikan ditentukan oleh kemampuan komunikator (Tuan Guru) menginformasikan pesan kegiatan pondok pesantren kepada masyarakat yang membuat masyarakat tahu dan memahami program pendidikan yang diselenggarakan oleh pondok pesantren sehingga mendorong mereka untuk ikut aktif dalam kegiatan pendidikan masyarakat.

Menurut TGH Anas Hasyiri, wujud dari keberhasilan komunikasi Tuan Guru nampak melalui pengetahuan, kemampuan, dan kredibilitas dalam menyampaikan penjelasan tentang manfaat kegiatan dan program pondok pesantren. Keberhasilan tersebut diwujudkan dalam keterlibatan masyarakat dalam kegiatan pendidikan yang diselenggarakan oleh pondok pesantren. Selain itu, komunikasi yang dilakukan oleh Tuan Guru tidak dilakukan dengan sering. Hal ini disebabkan karena sudah terbangun kesadaran pada masyarakat untuk terlibat dalam kegiatan-kegiatan yang berhubungan dengan pondok pesantren atau lebih khusus 
lagi dalam pembangunan masjib. Hal ini juga disebabkan oleh berjalannya fungsi komunikasi Tuan Guru. Dengan kata lain, TGH Anas Hasyiri beranggapan bahwa Tuan Guru sudah menjalankan tugasnya secara baik dalam memberikan penjelasan dan informasi tentang kegiatan pendidikan serta masyarakat sudah mendapat manfaat dari program yang ditawarkan oleh pondok pesantren.

Keterlibatan masyarakat dalam kegiatan-kegiatan atau program pondok pesantren didasarkan pada kepercayaan masyarakat kepada Tuan Guru. Kepercayaan tersebut diperlihatkan oleh pengetahuan yang luas, keimanan yang tinggi, dan kewarahan yang ditunjukkan oleh perbuatan atau aksi nyata Tuan Guru bagi masyarakat. Kepercayaan tersebut menyebabkan tidak adanya hambatan atau kesulitan dalam menyampaikan pesan atau informasi pendidikan kepada masyarakat. Hal ini disebabkan oleh adanya tingkat kesesuaian informasi antara program-program pondok pesantren (program pendidikan) dan kejelasan bahwa atau istilah yang digunakan oleh Tuan Guru. Kondisi ini menunjukkan bahwa komunikasi antara tuan guru sebagai pengelola pondok pesantren dan masyarakat sebagai penerima program pendidikan telah berjalan sebagaimana mestinya. Selain itu, kepercayaan tersebut memperlihatkan adanya komunikasi dialogis antara Tuan Guru dan masyarakat sehingga mendukung tercapainya setiap program atau kegiatan yang diselenggarakan oleh pondok pesantren. Hal ini menggambarkan bahwa program pendidikan yang ditawarkan oleh pondok pesantren telah dikomunikasikan kepada masyarakat tanpa adanya hambatan/gangguan yang berarti. Ini berarti bahwa program pendidikan telah berjalan sesuai dengan yang direncanakan.

Fenomena yang sama diakui Tuan Guru Haji Khairi Adnan bahwa sebelum menjadi Tuan Guru, masyarakat sudah percaya kepada Tuan Guru. Kepercayaan tersebut didasarkan pada dakwah bilhal - perbuatan nyata yang dilakukan oleh Tuan Guru. Perbuatan tersebutlah yang berbicara kepada masyarakat yang pada gilirannya meningkatkan partisipasi masyarakat dalam kegiatan atau program pondok pesantren. TGH Khairi Adnan menjelaskan bahwa dalam membangun, yang terpenting adalah kumpul - memdiskusikan hal-hal yang perlu dikerjakan bersama Tuan Guru, membicarakan persoalan yang dihadapi oleh pondok pesantren, tanpa membebani. Dengan mengundang masyarakat ke pondok pesantren, mereka tergerak hatinya membantu, tanpa diminta.

Tuan Guru Haji Khairi Adnan menjelaskan bahwa "masyarakat dapat berpartisipasi dalam berbagai bentuk, misalnya partisipasi material (barang dan uang), partisipasi fisik, partisipasi dalam bentuk doa, diam (tidak berbicara) juga salah satu bentuk partisipasi". Hal ini berarti ada banyak cara untuk berpartisipasi. Basarian atau bantuan kemanusiaan, seperti membantu korban banjir, membantu korban bencana alam, tsunami, dan gempa bumi, juga salah satu bentuk partisipasi.

Tuan Guru Haji Hasanain mengatakan bahwa cara untuk meningkatkan partisipasi masyarakat dalam kegiatan pendidikan dan kegiatan pondok pesantren dengan melakukan strategi komunikasi kedalam. Dalam berkomunikasi dengan 
masyarakat, Tuan Guru menekankan perlu mengesampingkan kepentingan pribadi, tetapi lebih mengutamakan kepentingan umat dan kepentingan agama. Hal ini berarti bahwa hubungan yang dibangun oleh Tuan Guru didasarkan pada hubungan yang tulus/ikhlas, tidak untuk mencari popularitas diri. Selain itu, Tuan Guru Haji Hasanain juga menekankan perlunya kesatuan antara kata dan perbuatan. Tuan Guru tidak hanya berbicara tentang Al Qur'an, Al Hadiths, dan Kitab Kuning, tetapi juga berbicara tentang 'kitab hijau' - pembumiannya dalam kehidupan praktis masyarakat, dalam program-program yang bermanfaat bagi masyarakat banyak. Inilah faktor yang mendorong keterlibatan masyarakat dalam setiap program atau kegiatan yang diselenggarakan oleh Tuan Guru Haji Hasanain atau oleh Pondok Pesantren Nurul Haramain Nurmada.

Tuan Guru berinteraksi melalui komunikasi interpersonal verbal maupun nonverbal, mengembangkan suatu ikatan secara psikologis dan sosial dalam suatu kelompok atau institusi, di mana interaksi simbolis menjadi dasar untuk menjelaskan bagaimana makna atas simbol-simbol dipahami dan dipikirkan tuan guru untuk menentukan tindakan mereka. Makna atas simbol yang mereka pahami akan semakin sempurna oleh karena adanya komunikasi interpersonal atau dialog, komunikasi yang tak termediasi dengan masyarakat dalam pendidikan (Craig and Muller, 2007:56-59). Simbol-simbol yang diciptakan, dipikirkan, dan dipahami Tuan Guru merupakan bahasa yang mengikat aktivitas di antara mereka dan kelompok di luar mereka.

\section{Komunikasi dalam Memotivasi masyarakat}

Hasil penelitian menggambarkan bahwa komunikasi dalam rangka memotivasi masyarakat dilakukan dalam berbagai bentuk komunikasi. Tuan Guru berinteraksi dengan masyarakat dalam tatanan komunikasi pribadi dan komunikasi kelompok. Peneliti memperoleh data penelitian yang menunjukkan bahwa komunikasi interpersonal menjadi kegiatan komunikasi yang mendominasi proses pemotivasian masyarakat. Komunikasi interpersonal ini dilakukan dalam kegiatan keseharian proses memberikan motivasi kepada masyarakat, seperti kegiatan temu siswa, temu santri, dan temu orang tua wali siswa atau orang tua wali santri.

Selain komunikasi interpersonal, dalam kegiatan pondok pesantren, Tuan Guru sering pula melakukan komunikasi kelompok. Hasil penelitian menggambarkan bahwa komunikasi ini dilakukan biasanya berkenaan dengan kegiatan penyampaian pesan yang bersifat formal dari Tuan Guru kepada para siswa, santri dan masyraakat. Komunikasi kelompok dilakukan seperti ketika memberikan informasi (sosialisasi) program yang akan dilakukan, melakukan pengajian, pertemuan majelis takhlim, pertemuan hajatan yang diselenggaraakan oleh masyarakat seperti khitanan, nikah, dan pertemuan klasikan dengan para siswa atau santri, dan pengkajian kitab kuning. Selain itu komunikasi kelompok juga dilakukan ketika mengadakan simulasi dalam hal berbagai kegiatan administrasi pondok pesantren. 
Bahasa yang digunakan oleh Tuan Guru dalam berkomunikasi dengan masyarakat selalu disesuaikan dengan situasi dan kondisi dari realitas interaksi yang terjadi. Bahasa keseharian yang digunakan oleh Tuan Guru untuk percakapan sebagian besar menggunakan bahasa campuran, yaitu bahasa Sasak dan bahasa Indonesia. Bahasa keseharian yang digunakan oleh sebagian besar informan penelitian adalah bahasa Sasak, namun demikian seringkali pula dalam penggunaannya bercampur dengan bahasa Indonesia.

Ketika berinteraksi dengan orang lain (sesama Tuan Guru, Masyarakat, santri dan siswa), Tuan Guru ingin menyajikan suatu gambaran diri yang akan diterima orang lain. Upaya tersebut sebagai impression management atau pengelolaan kesan, yaitu teknik yang digunakan Tuan Guru untuk memupuk kesan tertentu dalam situasi tertentu untuk mencapai tujuan tertentu. Untuk menimbulkan kesan tertentu, teknik yang digunakan Tuan Guru akan mempresentasikan dirinya melalui atribut atau tindakan tertentu, termasuk pakaian, tempat tinggal, perabotan rumah tangga, cara berjalan, gaya berbicara, dan sebagainya. Ketika berkomunikasi, tuan guru akan mengelola dirinya agar tampak seperti apa yang dikehendakinya, sebaliknya juga orang lain yang menjadi lawannya melakukan hal yang sama. Oleh karenanya, tuan guru melakukan pertunjukan bagi orang lain, sehingga ia menjadi aktor yang menunjukkan penampilannya untuk membuat kesan bagi lawannya.

Aktivitas kehidupan tuan guru di pondok pesantren bagaikan sebuah panggung pertunjukan. Para aktor (tuan guru) ingin menampilkan suatu performa yang ditujukan agar penonton (masyarakat dan santri) memiliki kesan terhadap apa yang ditampilkan tuan guru. Tentu saja kesan yang diharapkan dari masyarakat dan santri adalah seperti apa yang diharapkan tuan guru. Karena itulah tuan guru mempersiapkan pengaturan (setting), baik yang bersifat geografis maupun personal (personal front).

\section{SIMPULAN}

Komunikasi Tuan Guru dalam memotivasi masyarakat ditampilkan melalui komunikasi lisan (verbal dan nonverbal) dan komunikasi bilhal. Tipikasi Tuan Guru umumnya menampilkan komunikasi lisan (verbal dan nonverbal) yang relatif sama, tetapi menampilkan komunikasi bilhal yang relatif beragam sesuai dengan latar belakang pendidikan dan profesi Tuan Guru.

Komunikasi Tuan Guru untuk memberdayakan masyarakat dikonstruksi baik melalui simbol lisan (verbal dan nonverbal) maupun melalui simbol bilhal (perbuatan atau tindakan nyata). Tipikasi Tuan Guru menentukan perbedaan tampilan simbol komunikasi bilhal. Tuan Guru berbasis tradisional klutural lebih mengedepankan komunikasi lisan (verbal dan nonverbal) daripada komunikasi bilhal, sedangkan Tuan Guru berbasis formal-organik lebih mengedepankan integrasi antara komunikasi lisan dan bilhal bahkan lebih menekankan komunikasi bilhal daripada komunikasi lisan.

Komunikasi Tuan Guru untuk meningkatkan partisipasi, keterlibatan emosional, kontribusi, dan tanggung jawab masyarakat tidak hanya ditampilkan 
melalui komunikasi lisan (pengajian kitab, ceramah, tabliq) tetapi juga ditampilkan melalui komunikasi bilhal (sedekah, perilaku tulus, ikhlas, dan pembangunan dan pengembangan lembaga pendidikan, pengembangan ekonomi, pendidikan lingkungan dan demokrasi). Integrasi antara komunikasi lisan dan bilhal memperlihatkan jati diri seorang Tuan Guru sebagai agamawan organik yang berinteraksi untuk meningkatkan keterlibatan emosional, kontribusi, dan tanggung jawab masyarakat bagi pencapaian tujuan pendidikan pondok pesantren.

\section{DAFTAR PUSTAKA}

Craig, Robert T dan Heidi L. Muller. 2007. Theorizing Communication: Reading Across Tradition. New Delhi India: Sage Publication, Inc

Ndraha, Taliziduhu, 1997. Pembangunan Masyarakat Mempersiapkan Masyarakat Tinggal Landas. Jakarta: Bina Aksara.

Schutz, Alfred. 1967. The Phenomenology of the Social World. Trans. G. Walsh and F. Lehnert. Evanston, IL: Northwestern University Press.

Schutz, Alfred and Thomas Luckmann. 1973. The Structures of the Life-World. Trans. R. M. Zaner and H. T. Engelhardt, Jr. Evanston, IL: Northwestern University Press. 